\title{
PĂRĂSIREA LUMII ŞI INTRAREA ÎN MONAHISM
}

\author{
†Nicodim Nicolăescu*
}

\begin{abstract}
Giving up the world means the decision of a person to bear not ordinary his cross, founding a family, but willingly having another cross, as a monk in a monastery with community life or in seclusion as an eremite (anchorite). Along with the novice decision for the kingdom of freedom - as it is known the seclusion life - there starts coming temptations by the devil in order to convince him to quit his way. In the same way, as well as the novice enters into a monastery, he has to face trials and temptations in order to determine if the newcomer has the qualities required for a monk. This is named luring canonical. In the monastery, the novice has his spiritual fathers as model. The philokalia's parents had noted the necessary virtues of a monk along his life. Among them prominent place have humility, patience, devotion to prayer and to the sacred services.
\end{abstract}

Keywords: monastery, monk, temptation, novice, anchorite.

\section{Preliminarii}

Creștinul, pe tot parcursul vieții sale, este îndatorat, printre altele, a duce o viață morală, împlinind poruncile lui Dumnezeu. Aceste porunci dumnezeieşti, pe care creştinul trebuie să le cunoască, îi sunt călăuză în viață. Cunoscând poruncile şi împlinindu-le, el, creştinul, isşi arată iubirea sa față de Dumnezeu, după cum spune Domnul nostru Iisus Hristos: „Cel ce are poruncile Mele şi le păzeşte, acela este care Mă iubeşte; iar cel care Mă iubeşte pe Mine va fi iubit de Tatăl Meu şi-l voi iubi şi Eu şi Mă voi arăta lui" (Ioan 14, 21). Prin Moise, Dumnezeu a rânduit spre călăuză poporului ales cele zece porunci, iar apoi, Iisus Hristos, fiind întrebat de unul dintre

\footnotetext{
* Bishop of Severin and Strehaia, PhD, Associate Professor at the Faculty of Orthodox Theology of the University of Craiova, Romania.
} 
ispititori care este cea mai mare poruncă din lege, îi răspunde: „Să iubeşti pe Domnul Dumnezeul tău cu toată inima ta, cu tot sufletul tău şi cu tot cugetul tău. Aceasta este marea şi întâia poruncă. Iar a doua, la fel ca aceasta: Să iubeşti pe aproapele tău ca pe tine însuți"” (Matei 22, 37-39).

Referitor la prima poruncă arătată de Mântuitorul, Sfântul Antonie cel Mare spune: "Mintea iubitoare de Dumnezeu este binefăcătoarea şi mântuitoarea sufletului omenesc"1. Asemenea legilor şi canoanelor, poruncile sunt obligatorii, au un caracter de obligativitate. În afară de poruncile dumnezeieşti, la care se adaugă şi celelalte nouă porunci bisericeşti, mai există şi sfaturile evanghelice, pe care cei râvnitori şi cu multă evlavie le împlinesc. Sfaturile evanghelice nu sunt obligatorii, însă în momentul în care devin voturi, după depunerea jurământului la tunderea în monahism, sunt obligatorii. Cel ce a depus voturile monahale devine călugăr sau monah. În viaţa de mânăstire, el, monahul, se socoteşte pe sine una cu toți, deoarece i se pare că se vede pe sine necontenit în fiecare, după cum zice Evagrie Ponticul ${ }^{2}$.

\section{Hotărârea de a părăsi lumea pentru a deveni monah}

Creştinii pot să împlinească şi în lume unul sau mai multe din sfaturile evanghelice. Aceasta depinde de voința şi râvna, evlavia şi credința fiecărui credincios în parte. În schimb urcuşul spre desăvârşire este asigurat de împlinirea sfaturilor evanghelice în viața de obşte a mânăstirii. Pentru a se apropia de Iisus Hristos pe această cale, credinciosul dornic de a îmbrățişa viața de mânăstire simte o chemare în acest sens, se observă la el vocația şi dorința de a renunţa

${ }^{1}$ Sfântul Antonie cel Mare, Învătături despre viața morală a oamenilor şi despre buna purtare, in 170 de capete, 94, în col. „Filocalia românească” (în continuare Fil. rom.), vol. 1, trad., introd. şi note de Pr. Prof. dr. Dumitru Stăniloae, Bucureşti, Editura Institutului Biblic şi de Misiune al Bisericii Ortodoxe Române (în continuare EdIBMBOR), 2008, p. 34.

${ }^{2}$ Evagrie Ponticul, Cuvânt despre rugăciune, impărțit în 153 de capete, 125, în col. Fil. rom., vol. 1, ed. cit., p. 115. 
la lume. Într-un cuvânt, pentru a porni cineva pe calea împărătească, cum spuneau părinții, este necesară o neclintită hotărâre pentru a îndeplini sfaturile evanghelice în viața de mânăstire.

Este foarte greu ca cineva să împlinească în totalitate sfaturile evanghelice în lume, de aceea creştinul care doreşte să urmeze această cale trebuie să fie hotărât pentru a renunţa la lume. A renunța la lume înseamnă a renunța la căsnicie, la viaţa de familie şi la tot ceea ce implică aceasta, în favoarea dorinței de a împlini sfaturile evanghelice. Hotărârea se ia în urma unei chibzuite cugetări, nu cu uşurință, nici în urma unor necazuri sau greutăți. De cele mai multe ori gândul sau cugetul acesta vine de la Dumnezeu, este glasul chemării. Sfântul Antonie s-a hotărât să renunțe la lume după ce împlinise vârsta de $20 \mathrm{de}$ ani $^{3}$. La citirea Sfântei Evanghelii, în cadrul Sfintei Liturghii, a auzit chemarea Mântuitorului „Cel ce voieşte să vină după Mine, să se lepede de sine, să-şi ia crucea sa şi să-mi urmeze Mie" (Luca 9, 23). În acel moment s-a hotărât să părăsească lumea, cetatea, totul.

Este foarte important ca această hotărâre să se ia în mod conştient şi liber nu din constrângere sau frică. În caz contrar sfatul este lipsit de condițiile sale fundamentale.

La Sfinții Părinți hotărârea de a renunța la viața de familie şi a intra în viața de mânăstire este exprimată prin ceea ce se cheamă "fuga de lume". Alteori întâlnim expresii ca "depărtarea de lume”, "desprinderea sau lepădarea de lume” sau chiar „părăsirea lumii”. Astfel în Pateric întreg capitolul al XX-lea este întitulat: „Pentru lepădarea de lume şi cum că cel ce se leapădă de lume trebuie să se înstrăineze şi care este înstrăinarea cea adevărată" ${ }^{4}$. Învățăturile care se desprind din acest capitol au menirea de a-1 întări pe cel ce a renunțat la lume să nu se mai întoarcă înapoi. Un bătrân preciza că

„la începutul lepădării monahului de lume, nu se slobod dracii să ispitească pre om cu silnicie, ca nu spăimântându-se de lucru

${ }^{3}$ Arhim. Efrem Enăcescu, Privire generală asupra monahismului creştin, Tipografia „Cozia” a Sfintei Episcopii a Râmnicului Vîlcii, 1933, p. 27.

${ }^{4}$ (...), Patericul, Bucureșii, 1976, p. 419. 
să se întoarcă la lume degrab. Iar dacă cu vremea şi cu lucrul va spori monahul, atunci se slobod asupră-i războaiele poftelor trupeşti şi ale celorlalte dezmierdări, poate încă și al mâniei, al urâciunei şi al celorlalte patimi. Şi atunci nevoie are omul să se smerească și să plângă, osândindu-se şi prihănindu-se pre sine numai. Şi aşa prin ispite se învață răbdarea iscusită şi dreapta socoteală, apoi aleargă la Dumnezeu cu lacrămi" 5 . Un alt bătrân îndeamnă la îndepărtarea de oamenii împătimiți care trăiesc în lume: „Trebuie să fugim de toți cei ce lucrează fărădelegea, măcar prieteni sau rude de ne vor fi, măcar dregătorie preoțească sau împărătească de vor avea. Că depărtarea de la cei ce lucrează fărădelegea ne dăruiește nouă dragostea și îndrăzneala către Dumnezeu"

Pentru monah lumea a murit. În războiul nevăzut, el rabdă încercările cu multă bucurie. Sfântul Isaac Sirul scrie despre cei ce au lăsat lumea:

„Cei pentru care lumea a murit rabdă încercările cu bucurie. Iar cei pentru care lumea e vie nu pot răbda nedreptătile sau se mânie, împinşi de slavă deșartă şi se tulbură fără judecată, sau sunt topiți de întristări. Cât de greu de dobândit este virtutea răbdării și câtă slavă ne aduce ea de la Dumnezeu! Cel ce voiește să dobândească virtutea aceasta... trebuie să se depărteze de ai săi și să se înstrăineze" ${ }^{7}$.

Cei pentru care lumea e vie, după expresia Sfântului Isaac Sirul, atunci când se întorc iarăşi în mijlocul lumii şi renunță să-şi împlinească făgăduința nu-şi găsesc locul, nu se simt bine. Despre un astfel de om care-şi calcă făgăduința se spune că e un om mort, altfel spus, monahul întors în lume miroase ca un mort. Sfântul Ioan Scărarul zice monahului: „Locul acesta să-ți fie ție mormânt înainte de mormânt. Şi nimeni nu iese din mormânt înainte de învierea cea

5 (...), Patericul, ediția a III-a, Râmnicu-Vâlcea, Tiparul tipografiei Cozia, 1930, pp. $423-424$.

${ }^{6}$ Ibidem, p. 426.

Sfântul Isaac Sirul, Cuvinte despre nevoință, în Fil. rom, vol. 10, p. 55;

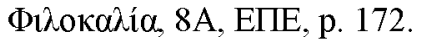


de obşte. Iar de au ieşit unii, ia seama că mai înainte au murit. Să rugăm pe Domnul să nu pătimim şi noi aceasta"8.

Sfântul Isac Sirul, referindu-se la păzirea şi menținerea hotărârii cu privire la împlinirea până la sfârşit a „lepădării de lume”, îndeamnă la depărtarea de pricinile păcatului ${ }^{9}$. În scrierile sale întâlnim expresiile "fuga de lume"10 "depărtarea de lume" „lepădarea de lume"12. Fără depărtarea de lume nu se pot împlini cum se cuvine sfaturile, căci spune tot Sfântul Isaac Sirul în Cuvinte despre nevoință: „Nimeni nu poate să se apropie de Dumnezeu decât dacă se depărtează de lume. Iar lepădare numesc nu ieşirea din ea cu trupul, ci depărtarea de lucrurile lumii. Virtutea aceasta stă în odihnirea sau golirea cugetării de lucrurile lumii”"13.

Hotărârea de a împlini sau mai exact de a făgădui împlinirea sfaturilor evanghelice nu se ia de cei cu inimile cuprinse de frică. Îndoiala de a nu putea ține făgăduința până la sfârşit este o ispită adusă de diavol. Nu ne poate ispiti decât dacă îngăduie Dumnezeu. În acest sens, Sfântul Isac Sirul scrie pentru cei chemați către viața de mânăstire:

„De te simți vreodată pregătit pentru retragerea în singurătate (mânăstire) în împărăția libertății, ale cărei sarcini sunt ușoare, să nu te împingă cugetul fricii, după obiceiul lui, în multe feluri de schimbări și învârtiri ale gândurilor, ci fii mai degrabă încrezător că păzitorul tău este cu tine și încredințează-te cu dinadinsul întru înțelepciunea ta, că tu şi toată zidirea sunteți sub singurul Stăpân care, cu o singură încuviințare, toate le mişcă, le clatină, le îmblânzește și le călăuzește şi ridică-te îndată și îndrăznește, căci, chiar de s-a dat unora slobozenie în unele lucruri, nu li s-a dat în toate lucrurile. Căci nici dracii, nici fiarele

${ }^{8}$ Sfântul Ioan Scărarul, Scara dumnezeiescului urcuş, Cuvântul IV, 93, în Fil. rom., vol. 9, trad., introd. şi note de Pr. Prof. dr. Dumitru Stăniloae, București, EIBMBOR, 2013, pp. 148-149.

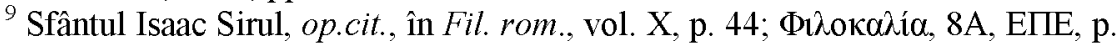
144.

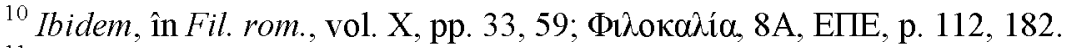

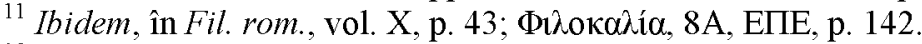

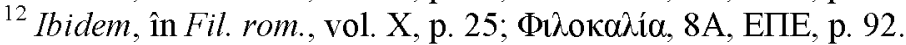

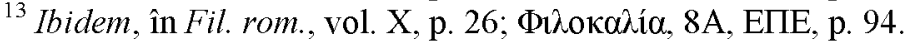


pierzătoare, nici oamenii stăpâniți de răutate nu pot împlini voia lor pornită spre nimicire și pierzanie, de nu va îngădui voia Celui ce le cârmuiește pe toate şi le dă un anumit loc de lucrare. Căci nu îngăduie libertății lor să vină la toată lucrarea. Pentru că de-ar fi așa, n-ar putea viețui nici un trup. Nu lasă Dumnezeu ca de zidirea Lui să se apropie puterea dracilor și a oamenilor și să-şi împlinească în ea voia lor"14.

Vrăjmaşul diavol încearcă să-1 determine pe om să renunțe la orice gând bun, la hotărârea de a lăsa toate ale lumii pentru Hristos sau la orice virtute. Sfântul Isaac ne îndeamnă:

„Când voieşti să pui începutul unei lucrări bune, pregătește-te pentru ispitele ce vor fi aduse asupra ta şi să nu te îndoiești de adevăr. Căci e un obicei al vrăjmașului ca, atunci când vede pe cineva începând cu credință fierbinte o bună viețuire, să-i aducă în cale ispite felurite şi înfricoşătoare, ca venind prin aceasta la frică, să-şi răcească hotărârea lui cea bună și să nu mai aibă râvnă fierbinte de a se apuca de lucrarea plăcută lui Dumnezeu"15.

Fratele nu trebuie să se îndoiască de ajutorul lui Dumnezeu şi să se lase cuprins de frică. „Omul care se îndoiește că Dumnezeu îi ajută în lucrarea virtuţilor se teme chiar şi de umbra sa şi se socoteşte flămând chiar şi în vremea îmbelşugării şi a săturării”" ${ }^{6}$.

\section{Părăsirea lumii şi intrarea în monahism la Părinții filocalici.}

Avva Dorothei, inspirat din scrierile Sfântului Ioan Casian, s-a referit la părăsirea lumii sau fuga de lume şi intrarea în monahism.

„Noi am socotit că ne răstignim nouă lumea, când am părăsit-o şi am venit în mânăstire; dar nu voim să ne răstignim și pe noi înşine lumii. Căci avem încă plăcerile față de ea, avem încă împătimirile față de ea, pătimim încă de slava ei, pătimim încă de mâncăruri şi de haine. Căci de e vreo unealtă frumoasă şi suntem împătimiți de ea şi lăsăm această mică unealtă să ne stăpânească, cum a zis Avva Zosima, ținând

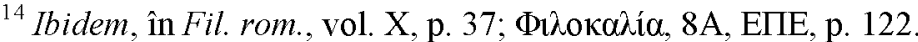

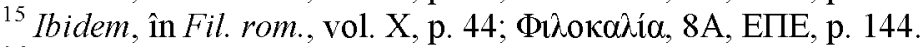

${ }^{16}$ Ibidem.
} 
la ea ca la o sută de livre de aur, chiar dacă socotim că am ieşit din lume și am lăsat cele ale ei şi am venit în mânăstire, ne aflăm prin lucruri neînsemnate împătimiți de ea. Aceasta o pătimim din multa lipsă de minte, căci lăsând lucrurile mari și de mare preț, ne împlinim patimile noastre prin unele foarte mici (...) precum am spus prin lucruri neînsemnate și de nimic, mulțumim împătimirea noastră. Dar nu trebuie să facem așa. Ci precum ne-am lepădat de lume și de lucrurile din ea, aşa trebuie să ne lepădăm şi de împătimirea față de lucrurile din ea, şi să ştim ce este lepădarea și pentru ce am venit în mânăstire şi ce este schima pe care am luat-o, şi să ne potrivim ei şi să ne nevoim asemenea părinților noștri (spirituali) ${ }^{\prime 17}$.

Sfântul Ioan Casian spune:

„Ei chibzuiesc că, decât să fii sărac, mai fericit lucru este a stăpâni peste o bogăție proprie şi din prisosul ei a da şi celor ce au lipsă. Să știe însă că unii ca aceștia încă nu s-au lepădat de lume, nici n-au ajuns la desăvârşirea monahicească, dacă se rușinează de Hristos şi nu iau asupra lor sărăcia Apostolului, ca prin lucrul mâinilor să şi slujească lor și celor ce au trebuință, spre a împlini făgăduința călugărească și a fi încununați cu Apostolul, ca unii care după ce şi-au risipit vechea bogăție luptă ca Pavel lupta cea bună în foame şi în sete, în ger şi fără haine (2 Tim. 4,7). Căci dacă apostolul ar fi știut că pentru desăvârşire mai de trebuință este vechea bogăție, nu şi-ar fi disprețuit starea de cinste, căci zice despre sine că a fost om de vază şi cetătean roman (Fapte 22, 25). Asemenea şi cei din Ierusalim, care îşi vindeau casele şi țarinile și puneau prețul la picioarele apostolilor (Fapte 4,35) n-ar fi făcut aceasta dacă ar fi știut că apostolii țin de lucru mai fericit şi mai chibzuit ca fiecare să se hrănească din banii săi, şi nu din osteneala proprie şi din ceea ce aduc neamurile" $" 18$.

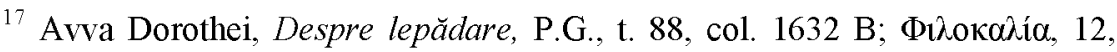
EПE, p. 280; Fil. rom., vol. IX, pp. 488-489.

${ }^{18}$ Sf. Ioan Casian, Despre cele opt gânduri ale răutăţii, în Fil. rom., vol. I, pp. 136-137. 
Părinţii duhovniceşti din mânăstirea Avvei Serid, Varsanufie Marele Bătrân şi Ioan, cel numit Profetul, au cugetat foarte mult la înstrăinarea cugetărilor lumeşti, la înstrăinarea gândurilor de lume, folosindu-i astfel pe ucenici. De pildă, Marele Bătrân precizează:

„Răspunsul aceluiaşi mare bătrân către acelaşi, pentru că fratele lui după trup, gândindu-se să se retragă în viạta călugărească, îl întrebase prin el pe bătrânul despre acesta: (...) Frate, nimenea voind să intre în cetate nu doarme; şi nimenea, vrând să lucreze, nu se lenevește văzând soarele; și nimenea vrând să-şi lucreze țarina nu stă nepăsător. Ci cel ce voiește să intre în cetate iuțeşte pasul, în loc să-1 facă mai zăbavnic; şi cel ce vede soarele începe repede să lucreze de frică să nu fie în curând împiedicat; şi cel ce voiește să-şi lucreze ţarina, se grăbește ca să nu fie vătămată de neghină. Cel ce are urechi, să audă" ${ }^{, 19}$.

În cele de mai sus Marele Bătrân condamnă amânarea de a părăsi lumea. E vorba de renunțarea la urcuşul duhovnicesc. În felul acesta, renunțarea devine obişnuință, de care se scapă greu. Părintele Stăniloae, comentând aceasta, spune că oprirea din urcuş însemnează căderea în aceeaşi clipă mai jos de unde a fost persoana respectivă ${ }^{20}$.

Deşi au dorit să aibă frați şi ucenici câți mai mulți, Marele Bătrân nu îngăduia ca un bărbat să-şi lase viața de familie, să-şi lase femeia şi să meargă la mânăstire, fie şi din evlavie multă. El răspunde celui ce întreabă dacă este de folos să se despartă de femeia lui pentru a se călugări: „Fiule, nu te despărți de ea, căci prin aceasta calci porunca apostolului, care zice: «Te-ai legat cu femeia, nu căuta dezlegare» (I Cor. 7, 27). Căci altfel, dacă ea păcătuieşte şi se îndreaptă spre rău, păcatul cade asupra ta, afară de cazul când despărțirea s-a făcut cu buna învoire şi prin împreuna sfătuire"21.

${ }^{19}$ Evagrie Ponticul, Capete despre deosebirea patimilor şi a gândurilor, în Fil. rom., vol. I, pp. 56-57.

${ }^{20}$ Sf. Varsanufie şi Ioan, Scrisori duhovnceşti, în Fil. rom., vol. XI, nota 48, p. 57.

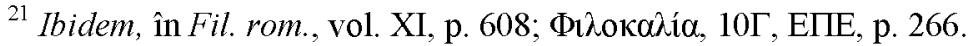


Începătorii erau îndrumați, în mânăstirea Avei Dorothei, să petreacă în smerenie, să nu se prețuiască pe sine, în orice situație s-ar afla, ci să petreacă în ascultare şi tăierea voii.

„Iar rânduiala începătorului este aceasta: să petreacă în multă smerenie, să nu se prețuiască pe sine în vreo privință oarecare, să nu zică: «Ce-i aceasta?», sau: «Pentru ce aceasta?». Ci întru multa ascultare şi supunere să nu se socotească deopotrivă cu cineva. Să nu spună: «I se dă cinste cutăruia, de ce nu mi se dă şi mie? E uşurat acela în toate, de ce nu sunt uşurat și eu?». Chiar dacă e băgat în seamă în toate să nu se împotrivească. Acestea sunt faptele adevăratului începător care vrea cu adevărat să se mântuiască" ${ }^{22}$.

Trăitor într-o mânăstire cu viaţă de obşte, Avva Dorothei consideră că mânăstirile sunt un trup, iar viețuitorii devin mădulare unii altora, conducătorii devin capul ș.a.m.d. Iată cum formulează el:

„Ce socotim noi că sunt mânăstirile de obște? Nu socotim că sunt un trup şi, cei din ele, mădulare unii altora? Cei ce conduc sunt capul; cei ce iau aminte şi îndreptează sunt ochii; cei ce folosesc pe alții prin cuvânt, gura. Iar urechile sunt cei ce ascultă; mâinile, cei ce lucrează; picioarele, cei trimişi (după cele de trebuinţă) şi cei ce au felurite slujiri. Eşti cap? condu! Ești ochi? ia aminte, cunoaşte! Ești gură? grăieşte, fii de folos! Eşti ureche? ascultă! Eşti mână? lucrează! Eşti picior? slujeşte! Fiecare să slujească trupului după puterea lui şi sârguiți-vă pururea să vă ajutați unii pe alții, fie învățând şi sădind cuvântul lui Dumnezeu în inima fratelui, fie mângâindu-l în vreme de necaz sau dându-i mâna la lucrul lui, ajutându-l. Şi fiecare, cum am spus, după puterea lui. Sârguiți-vă, să vă uniți unii întreolaltă. Căci pe cât se uneşte cineva cu aproapele, pe atât se uneşte cu Dumnezeu" 23 .

În viaţa de mânăstire, slujbele şi rugăciunile din timpul lor au menirea de a întării duhovniceşte pe monahii care locuiesc în număr mare în chinovii. Rânduielile slujbelor din mânăstirile cu viaţă de obşte sunt prezentate astfel:

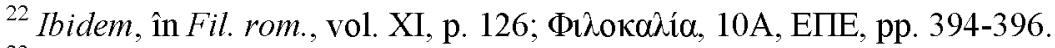

${ }^{23}$ Avva Dorothei, Să nu judecăm pe aproapele, P.G., t. 88, col. 1696 AB;

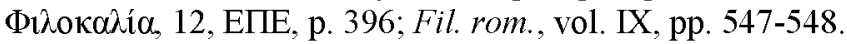


„Iar la Vecernie cei din schit spun doisprezece psalmi şi la sfârșitul fiecăruia, în locul doxologiei Mărire Tatălui etc. spun Aliluia şi fac rugăciune. La fel şi noaptea spun doisprezece psalmi şi după psalmi se aşează la lucrul de mână. Şi precum voiește unul spune psalmii din inimă, altul îşi cercetează gândurile sale sau viețile părinților. Acesta citind de cinci sau opt foi, trece apoi la lucrul de mână. Iar cel ce cântă sau rosteşte psalmii din inimă trebuie să-i rostească cu buzele, dacă nu-i aproape de el un altul şi dacă nu vrea ca nimenea să nu afle ce face".

De asemenea, el face o comparație între viaţa idioritmică şi viața de obşte:

„Cei din schit nu au nici ceasurile şi nu cântă nici imne, ci săvârşesc lucru de mână şi meditează şi fac câtă puţină rugăciune de unul singur. Iar stând la rugăciune trebuie să te rogi şi să te eliberezi de omul cel vechi, sau să zici «Tatăl nostru» sau să le faci pe amândouă şi apoi să șezi la lucrul de mână. Cât privește prelungirea rugăciunii, când stai în picioare, dacă te rogi neîncetat, potrivit Apostolului (I Tes. 5, 17), nu trebuie să o reiei de câte ori te ridici. Căci mintea ta e toată ziua în rugăciune. Dar când te aşezi la lucrul de mână trebuie să spui din inimă sau să rosteşti psalmi. Iar la sfârşitul fiecărui psalm să te rogi, şezând: «Dumnezeule, miluieşte-mă pe mine ticălosul!» Şi de ești hărțuit de gânduri adaugă: «Dumnezeule, Tu vezi necazul meu, ajutămă!». Când deci ai făcut trei rânduri în plasă, scoală-te la rugăciune. Şi plecând genunchiul şi sculându-te spune la fel rugăciunea amintită"24.

Avva Dorothei precizează, cu privire la monahi, rolul conştiinței, bazat pe învățătura Sfinților Părinți: „Iar părinții spun că monahul nu trebuie să lase conştiința sa să-l chinuiască niciodată, în nici un fel de lucru" 25 . Pentru a îndeplini cu frică de Dumnezeu şi iubire față de El voturile depuse, viețuitorii din sfintele mânăstiri şi cei care trăiau retraşi în pustiu se fereau să primească femei. Respingeau chiar şi pe acelea care veneau pentru sfat duhovnicesc

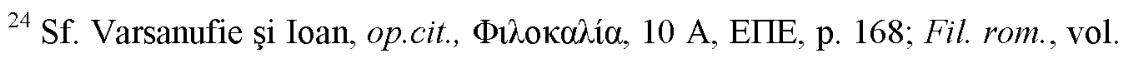
XI, p. 185.

${ }_{25}$ Avva Dorothei, Despre conştiință, P.G., t. 88, col. 1657 B; Ф1 EПE, pp. 328 - 330; Fil. rom., vol. IX, p. 512. 
sau cuvânt de folos. Unii mergeau până într-acolo încât la vederea unei femei strigau: „Fugiți, fraților, c-au venit hoții!””.

În ceea ce priveşte prezența femeilor la mânăstire, marele bătrân Varsanufie spune următoarele:

„Dacă se ivește prilejul să vină femei la voi pentru Dumnezeu, nu pentru a vedea locul, nici pentru a-şi face voia lor, ci în chip deosebit pentru a auzi cuvântul lui Dumnezeu sau pentru a aduce ceva mânăstirii și trebuie să vorbeşti cu ele, vorbeşte. Dar sileşte-te să-ţi păzești ochii, «pentru că cel ce privește la femeie spre a o pofti pe ea, a şi curvit în inima lui» (Mt. 5, 28) şi tot lucrul făcut pentru Dumnezeu e acoperit de Dumnezeu. Deci îndreaptă-ți gândul spre Dumnezeu ca să nu lucrezi pentru a plăcea oamenilor, nici căutând laudă, ci din inimă curată $^{, 26}$.

\section{Primirea în mânăstire. Ispitirea canonică}

În trecut primirea în mânăstire se acorda cu oarecare greutate de către Părinți. Cel care se prezenta la mânăstire solicitând integrarea în viaţa de obşte trebuia uneori multe zile să aştepte la poartă. În felul acesta i se încerca răbdarea după rânduiala Cuviosului Pahomie, care recomanda o oarecare alegere ${ }^{27}$ şi selectare. Ceilalți frați din obşte îl priveau pe novice cu oarecare dispreț, ba chiar îl şi ocărau. Prin aceste încercări întâistătătorul vroia să se convingă dacă nu cumva hotărârea solicitantului este trecătoare sau îndoielnică. În felul acesta era verificat dacă este îndeajuns de pregătit de a înfrunta orice ispită ${ }^{28}$. Încercarea celui ce solicita intrarea în mânăstire a fost prezentă şi în tradiția mănăstirească din România. În lucrarea Tradiție şi libertate in spiritualitatea ortodoxă, marele mitropolit al Ardealului, Antonie Plămădeală, prezintă felul în care aveau loc

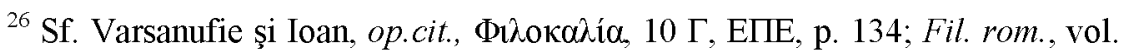
XI, p. 550.

27 Teofan Zăvorâtul, Rânduielile vieții monahale, pp. 78; Ierom. Nicodim Sachelarie, Asceza Creştină, Tip. Sf. Mitropolii a Olteniei, Craiova, 1942, p. 78 .

${ }^{28}$ Teofan Zăvorâtul, op.cit., p. 78. 
ispitirile canonice la mânăstirea Sihăstria în vremea starețului Ioanichie Moroi. El descrie felul în care s-a încercat răbdarea fratelui Constantin Ilie, cel care avea să devină Părintele Cleopa Ilie, unul dintre cei mai mari duhovnici care au luminat Biserica Ortodoxă Română în cea de-a doua jumătate a secolului al XX-lea. Timp de trei zile a trebuit să bată cu o nuia într-un trunchi putred de salcie ce se afla la poarta mânăstiriii ${ }^{29}$.

Stareții sfintelor mânăstiri au avut grijă ca făgăduința împlinirii sfaturilor evanghelice să nu fie făcută prea în grabă sau fără discernământul cuvenit, de aceea nu acordau uşor primirea în mânăstire. În această privință se povestește în ,Apophegmata Saneti Macarii Aegyptii” următoarele: „Avva Vitimiu povestea că Avva Macarie spunea: Pe când mă aflam odată în Skitis au coborât la mine doi tineri străini: unul dintre ei avea barbă, iar celuilalt abia dacă începuse să-i crească. Şi venind la mine mi-au zis: unde este chilia lui Avva Macarie? Dar eu le-am spus: „Ce aveți cu el? $\square$ i tinerii au zis: Auzind cele cu privire la el şi cele cu privire la Skitis, am venit să-l vedem. Le-am spus atunci: Eu sunt: Şi au depus metanie şi au zis: Voim să rămânem aici. Iar eu văzându-i gingaşi ca pe unii care veneau din lumea celor bogați, le-am spus: Nu puteți sta aici! Dar cel mai mare a zis: Dacă nu putem sta aici, atunci vom merge în altă parte? Şi atunci mi-am zis în gând: „Pentru ce să-i alung şi să-i scandalizez? Şi aşa oboseala îi va face să plece singuri. Şi le-am zis: Hai să vă faceți chilii dacă puteți. Şi ei mi-au spus: Arată-ne loc şi ne vom face. Deci, bătrânul le-a dat o secure şi le-a arătat o stâncă tare zicându-le: Tăiaţi piatră aici şi aduceți-vă lemne din pădure şi rămâneți aici. Socoteam - zicea el - că din cauza oboselii aveau să plece. Şi m-au întrebat: Ce vom lucra aici? Iar eu le-am spus: Împletitură şi am luat o ramură din pădure şi le-am arătat cum se împleteşte şi cum trebuie să coasă împletitura şi le-am zis: Faceți coşuri şi aduceți-le paznicilor şi vă vor aduce pâini. Deci eu am plecat mai departe. Aceştia au rămas mai departe acolo, lucrând, 29 Antonie Plămădeală, Traditie şi libertate in spiritualitatea ortodoxă,
Tipografia eparhială Sibiu, 1995, pp. 37-39. 
tăcând şi rugându-se până ce s-au pristăvit întru sfințenie" ${ }^{30}$. La moartea lor Avva Macarie a chemat pe alți monahi şi le-a zis „Veniți de vedeți meritul micilor pelerini" ${ }^{\prime 3}$.

Hotărârea de-a îmbrătiş̧a viața monahală nu se ia în urma unui mare necaz, a unei spaime, ci trebuie să fie un act cu totul conştient şi liber. Când făgăduința este făcută din frică sau din constrângere nu este ținută. Hotărârea în acest caz este încălcată după o anumită perioadă de timp. Avem de-a face cu renunțarea la chipul îngeresc şi cu o întoarcere la lume. Căutând să-şi motiveze ieşirea din disciplina vieții monahale, prin călcarea voturilor, Luther susținea că hotărârea o luase în urma unei spaime. A fost primit în viața de mânăstire, a depus voturile monahale, adică a făcut făgăduință împlinirii sfaturilor evanghelice. Spaima care a precedat hotărârea a fost pricinuită de o mare furtună la intrarea în oraşul Erfurt când viața i-a fost în pericol. El însuşi mărturiseşte: Sub imperiul spaimei am făcut un vot constrâns şi forțat ${ }^{32}$. Din aceste motive solicitantul este mult încercat la început. Este mult mai bine ca el să renunțe la început la hotărârea sa, decât după depunerea voturilor, care se face după minimum trei ani. Mai devreme, făgăduința se acceptă numai în cazuri excepționale, dar cu multă rezervă şi reținere şi, atunci, toată purtarea de grijă revine întâistătătorului.

Biserica a fost şi ea preocupată de felul în care se acceptă primirea în viața de mânăstire a celui ce doreşte să îmbrățişeze chipul cel îngeresc. Iată ce s-a statornicit în această privință la al V-lea Sinod Ecumenic, în Canonul 401:

„Fiindcă este faptă foarte mântuitoare a se lipi cineva de Dumnezeu prin retragerea din zgomotul vieții, ni se cuvine să nu primim cu pripă, fără examinare pe cei ce aleg viața monahală şi să păstrăm norma predanisită nouă în privința aceasta de către Sfinții Părinți. Astfel ca atunci să primim votul vieții celei după Dumnezeu,

${ }^{30}$ Protos. Emilian Birdaș, Originea istorică a voturilor monahale, în „Glasul Bisericii”, anul XIII, nr. 9-10, 1954, p. 515.

${ }^{31}$ Ibidem, p. 516.

${ }^{32}$ Ibidem, p. 515. 
când este întărit şi făcut prin cunoaștere și judecată după dezvoltarea deplină a rațiuniii”33.

Hotărârea a fost recunoscută și la Sinodul al VI-lea ecumenic şi la sinodul Trulan din anul 692.

După mai multe încercări şi ispitiri la poarta mânăstirii, starețul aprobă primirea solicitantului de a intra în rândul fraților. După ce primeşte această binecuvântare de a petrece în mijlocul fraților $^{34}$, începătorul învață rugăciuni, începe să deprindă rânduiala sfintelor slujbe, învățăturile dreptei credințe. Odată cu primirea, încercările nu încetează, ele se continuă până când întâistătătorul mânăstirii se convinge că hotărârea este definitivă şi decide că începătorul poate să facă făgăduința împliniriii voturilor, poate să fie tuns în monahism.

Încercările care se fac mai înainte de tundere, care au menirea de a verifica ferma dorință a începătorului de a îmbrățişa îngerescul chip, precum şi trăirea lui sufletească, au fost statornicite la sinodul al V-lea Ecumenic şi de asemeni au fost recunoscute la Sinodul al VI-lea şi la Sinodul Trulan din 692. Astfel, în Canonul 41 se spune:

„Cei de prin cetăți sau sate, voind să se retragă în locuri închise şi să se îngrijească de sine în singurătate, mai întâi trebuie să intre în mânăstire şi să se deprindă cu viața singuratică şi vreme de trei ani să se supună exarhului mânăstirii întru frica Lui Dumnezeu și să împlinească ascultarea întru toate cum se cuvine şi astfel să mărturisească benevol şi din toată inima, după care să se cerceteze de superiorul locului. Astfel să petreacă sau să petreacă afară de locul închis ca mai bine să se arate intențiunea lor" ${ }^{35}$.

Regulamentul pentru organizarea şi funcționarea administrativă şi disciplinară a mânăstirilor, în vigoare din anul 1953, prevede ca de la admiterea în mânăstire începătorul să treacă în ascultare la un călăuzitor rânduit de stareț. Călăuzitorul este

${ }_{33}^{33}$ Ibidem, p. 515; Arhid. prof. dr. Ioan N. Floca, Canoanele Bisericii Ortodoxe, Sibiu, 1993, pp. 128-129.

${ }^{34}$ Teofan Zăvorâtul, op.cit., p. 632.

${ }^{35}$ Protos. Bmilian Birdaş, op.cit., p. 516. 
purtătorul de grijă al începătorului, este învățătorul lui. Dacă începătorul dă dovadă de o comportare cuviincioasă, starețul îl recomandă Chiriarhului pentru admiterea legală în rândul fraților ${ }^{36}$.

Încercările sau, mai exact, ispitirea canonică, durează până la tunderea în monahism ${ }^{37}$, când fratele începător depune voturile monahale şi când făgăduieşte în mod solemn împlinirea lor până la sfârşitul vieții. Se urmăreşte felul în care fratele începător primeşte pravila Bisericii, participă la sfintele slujbe, se integrează în viața de obşte şi dă dovadă de smerenie, tăcere, ,post modest şi cuviincios”, dacă are „Rugăciunea lui Iisus” în mintea şi în inima sa, nevoindu-se a-şi împreuna lucrul cu rugăciunea ${ }^{38}$.

\section{Concluzii}

Creştinii râvnitori îşi îndreaptă paşii pe calea împărătească a viețuirii în mânăstire, slujind lui Dumnezeu. Ei nu părăsesc lumea pentru că ar urâ-o, ci din iubire faţă de Dumnezeu. Este necesară menținerea acestei hotărâri pe care cel o ia pentru întreaga sa viață. Răbdând multe încercări şi ispite, monahul ajunge cu adevărat înger in trup. Foarte mulți au ajuns pe culmile cele înalte ale desăvârşirii, la îndumnezeire. Au fost trecuți în rândul sfinților numai o parte, cei mai cunoscuți. Mulți, însă, dintre cei ce-au părăsit lumea au fost ştiuți numai de Dumnezeu. Părinții filocalici au pus accentul pe paza gândurilor şi înstrăinarea de agitația lumească. Cei din lume care au chemare pentru viața monahală, dar amână sau nu sunt încă hotărâți, se obişnuiesc cu această stare care înseamnă cădere. Odată admişi în mânăstire, urmează perioada noviciatului, are loc ispitirea canonică ce ține până la depunerea voturilor monahale, adică tunderea în monahism.

${ }^{36}$ Regulamentul pentru organizarea şi functionarea administrativă şi disciplinară a mănăstirilor, în „Biserica Ortodoxă Română”, anul LXXXI, nr. 4, 1953 , p. 397.

${ }_{37}^{37}$ Ibidem, p. 397.

${ }^{38} \mathrm{Ibidem}$, p. 398. 